\title{
Prevalence of Anemia in Females with Diabetes Mellitus Type-II and Menopausal Females of Hyderabad, Sindh
}

\author{
Shafaq Ansari, Jamshed Warsi, Zulfiqar Laghari
}

\begin{abstract}
OBJECTIVE: To determine the prevalence of anemia, in menstruating normal, menstruating diabetic, menopausal normal, menopausal diabetic female.

METHODOLOGY: A comparative cross sectional study performed at the department of Physiology, Sindh University Jamshoro, from April-September 2019 in collaboration with Liaquat University Hospital Jamshoro/ Hyderabad. The diabetic females recruited from Liaquat medical hospital (LUH) Jamshoro/ Hyderabad and menopausal women of society after approval from the research ethical committee of institute. Random sampling technique was chosen for the study. After observing inclusion and exclusion criteria, total 200 females were included in this study. After explaining the purpose of study, verbal and written consent taken, complete blood picture (CBC) performed from all participants. Data was entered in excel sheet and in SPSS 21.0 version. Chi-square test applied.

RESULTS: The prevalence of anemia in menstruating normal, menstruating diabetics, menopausal normal, menopausal diabetic was reported $50.00 \%, 51.67 \%, 52.00 \%$ and $70.00 \%$ respectively. The highest prevalence was reported in menopausal diabetic female $(\mathbf{7 0} \%)$.

CONCLUSION: The study concludes that the prevalence of anemia in menopausal diabetic is more pronounced than in the other three study groups that are normal menstruating, diabetic menstruating and normal menopausal females. This is suggestive that cessation of menstruation added with diabeties is high risk factor for anemia.
\end{abstract}

KEY WORDS: Diabetes Mellitus, Menopause and Anemia.

This article may be cited as: Ansari S, Warsi J, Laghari Z. Prevalence of Anemia in Females with Diabetes Mellitus Type-II and Menopausal Females of Hyderabad, Sindh. J Liaquat Uni Med Health Sci. 2020;19(02):93-6. doi: 10.22442/jlumhs.201920669

\section{INTRODUCTION}

Anemia is a clinical condition which is detected either by less number of erythrocytes $\left(<4.2\right.$ million $\left./ \mathrm{mm}^{3}\right)$ or less hemoglobin level $(<12 \mathrm{~g} / \mathrm{dl})^{1}$. Anemia is highly prevalent in developing countries like Pakistan; in children $^{2}$, university students ${ }^{3}$ in pregnant female ${ }^{4}$. Anemia is more common in women as compared to men $^{5}$. The prevalence of anemia in young female was reported $80.37 \%$. However, neglected female's groups like diabetic menstruating female or menopausal diabetic group the prevalence of anemia is not carried out yet.

Diabetes Mellitus (DM) is the main cause of mortality and morbidity in established as well as in developing countries $^{7}$. According to the World Health Organization (WHO), DM will be the seventh leading cause of mortality by the year $2030^{8}$. The Diabetes Mellitus Type-II (T2DM) is caused by destruction of pancreatic $\beta$-cells and declined the secretion of insulin. The insulin resistance and reduced synthesis of insulin associated with obesity 9 . Insulin resistance decreases the glucose tolerance in peripheral tissues, muscle cells, results in hyperglycemia. The proinflammatory cytokines and interleukin- 6 effects on progenitor to erythropoiesis phases by the erythroid growth factor and apoptosis of immature erythrocytes ${ }^{10}$. The prevalence of anemia and diabetes after menopause was increased; Menopause is an important stage in the life and amenorrhea consecutively at least for 12 months. Interestingly, decrease number of red cell indices is reported in menopausal women ${ }^{11}$.

The complications of diabetes has always been linked with menopause in women; An earlier menopause is a main complication of type I diabetes while the early menopause has been linked with the risk of Diabetes Mellitus Type-II diabetes ${ }^{12}$. Conclusively the connection between anemia, diabetes and menopause is obvious; hence the main objective of the work was to carry out the prevalence of anemia in menstruating normal, menstruating diabetics, menopausal normal, menopausal diabetic female.

\section{METHODOLOGY}

A comparative cross-sectional study was performed at the department of Physiology, Sindh University Jamshoro, from April-September 2019 in collaboration with Liaquat University Hospital Jamshoro/ Hyderabad. Random sampling technique was chosen for the study. According to the general formula of biostatistics the sample size stands out to be $n=200$. Participant include in present study was known diabetic menstruating and menopausal women, and 
their counter control groups from Liaquat Medical Hospital Jamshoro / Hyderabad and from society of Hyderabad city. Apparently healthy females with normal menstrual cycles, known cases of diabetics and those who were on menopause with or without diabetics were recruited. Females with other co morbidities other than diabetes, with menopause of un -natural cause like surgical removal and on medication except for diabetes were excluded from the study. The known T2 diabetics, normal menstruating, menopausal T2 Diabetic and without T2 Diabetic females were included in present study. $5 \mathrm{ml}$ of blood drawn after all aseptic measures and was collected into EDTA test tubes. Complete blood picture (CBC) was performed by using $\mathrm{CBC}$ hematology analyzer Celltac Alpha MEK-6500 by Nihon Kohden Germany, in sterilized condition in Diagnostic Research laboratory LUMHS. The Data was entered in Excel sheet and also in SPSS version 21.0. Chi-square test applied and result shown as percentages and proportions.

\section{RESULTS}

The present study emphasizes on the prevalence of anemia in some novel groups. Anemia is determined on basis of WHO criterion ${ }^{1}$ as shown in Table I. The prevalence of anemia in menstruating normal is $50 \%$ (mild 38\%, moderate $12 \%$ and severe $00 \%$ ). In menstruating diabetes is 51.67 (mild $20 \%$, moderate $31.67 \%$ and severe $00 \%$ ). In menopausal normal is $52 \%$ (mild $30 \%$, moderate $22 \%$ and severe $00 \%$ ) and in menopausal diabetes is $70 \%$ (mild $30 \%$, moderate $40 \%$ and severe $00 \%$ ).

In menstruating normal female, the RBC count less than 4.2 (million $/ \mathrm{mm} 3$ ) were $6 \%$ whereas $94 \%$ were having normal RBC count. In menstruating diabetic, the RBC count less than 4.2 (million $/ \mathrm{mm} 3$ ) were $16.67 \%$ whereas $83.33 \%$ were having normal RBC count. In menopausal normal the RBC count less than 4.2 ( $\mathrm{million} / \mathrm{mm} 3$ ) were $20 \%$ whereas $80 \%$ were having normal RBC count. In menopausal diabetic, the RBC count less than $4.2(\mathrm{million} / \mathrm{mm} 3)$ were $21.67 \%$ whereas $78.33 \%$ were having normal RBC count. Hematocrit less than $40 \%$ was found $94 \%$ in menstruating normal, $(71.67 \%)$ in menstruating diabetic. (82\%) in menopausal normal $(80 \%)$ in

TABLE I: FREQUENCY DISTRIBUTION OF PARTICIPANTS BASED ON DIFFERENT CATEGORIES menopausal diabetic respectively.

Whereas; microcytosis having MCV less than 80 was found in $18(36 \%)$ in menstruating normal, 32(53.33 $\%)$ in menstruating diabetic, $15(30 \%)$ in menopausal normal and $29(48.33 \%)$ in menopausal diabetic respectively. Table II.

TABLE II: FREQUENCY OF PARTICIPANTS HAVING ANEMIC INDICATORS $(n=200)$

\begin{tabular}{|c|c|c|}
\hline & Anemic & Non-anemic \\
\hline \multirow{4}{*}{$\begin{array}{l}\text { Menstruating } \\
\text { Normal }\end{array}$} & $\begin{array}{c}\mathrm{Hb}<12.0(\mathrm{~g} / \mathrm{dl})=25 \\
(50.00 \%)\end{array}$ & $\begin{array}{c}\mathrm{Hb} \geq 12.0 \mathrm{gm} / \mathrm{dl}=25 \\
(50.00 \%)\end{array}$ \\
\hline & $\begin{array}{l}\mathrm{RBC}<4.2(\text { million/ } \\
\left.\mathrm{mm}^{3}\right)=03(6.00 \%)\end{array}$ & $\begin{array}{l}\mathrm{RBC} \geq 4.2 \text { (million/ } \\
\left.\mathrm{mm}^{3}\right)=47(94.00 \%)\end{array}$ \\
\hline & $\begin{array}{c}\operatorname{MCV}<80\left(\mu m^{3}\right)=18 \\
(36.00 \%)\end{array}$ & $\begin{array}{c}\mathrm{MCV} \geq 80\left(\mu \mathrm{m}^{3}\right)=32 \\
(64.00 \%)\end{array}$ \\
\hline & $\begin{array}{l}\text { Hematocrit }<40 \% \\
\quad=47(94.00 \%)\end{array}$ & $\begin{array}{l}\text { Hematocrit } \geq 40 \% \\
=03(6.00 \%)\end{array}$ \\
\hline \multirow{4}{*}{$\begin{array}{l}\text { Menstruating } \\
\text { Diabetic }\end{array}$} & $\begin{array}{c}\mathrm{Hb}<12.0 \mathrm{gm} / \mathrm{dl}=31 \\
(51.67 \%)\end{array}$ & $\begin{array}{c}\mathrm{Hb} \geq 12.0 \mathrm{gm} / \mathrm{dl}=29 \\
(48.33 \%)\end{array}$ \\
\hline & $\begin{array}{l}\mathrm{RBC}<4.2 \text { (million/ } \\
\left.\mathrm{mm}^{3}\right)=10(16.67 \%)\end{array}$ & $\begin{array}{l}\mathrm{RBC} \geq 4.2 \text { (million/ } \\
\left.\mathrm{mm}^{3}\right)=50(83.33 \%)\end{array}$ \\
\hline & $\begin{array}{c}\operatorname{MCV}<80\left(\mu m^{3}\right)=32 \\
(53.33 \%)\end{array}$ & $\begin{array}{c}\mathrm{MCV} \geq 80\left(\mu^{3}\right)=28 \\
(46.67 \%)\end{array}$ \\
\hline & $\begin{array}{c}\text { Hematocrit }<40 \% \\
=43(71.67 \%)\end{array}$ & $\begin{array}{c}\text { Hematocrit } \geq 40 \% \\
=17(28.33 \%)\end{array}$ \\
\hline \multirow{4}{*}{$\begin{array}{l}\text { Menopausal } \\
\text { Normal }\end{array}$} & $\begin{array}{c}\mathrm{Hb}<12.0 \mathrm{gm} / \mathrm{dl}=26 \\
((52.00 \%)\end{array}$ & $\begin{array}{c}\mathrm{Hb} \geq 12.0 \mathrm{gm} / \mathrm{dl}=24 \\
(48.00 \%)\end{array}$ \\
\hline & $\begin{array}{l}\mathrm{RBC}<4.2(\text { million/ } \\
\left.\mathrm{mm}^{3}\right)=10(20.00 \%)\end{array}$ & $\begin{array}{l}\mathrm{RBC} \geq 4.2 \text { (million/ } \\
\left.\mathrm{mm}^{3}\right)=40(80.00 \%)\end{array}$ \\
\hline & $\begin{array}{c}\operatorname{MCV}<80\left(\mu \mathrm{m}^{3}\right)=15 \\
(30.00 \%)\end{array}$ & $\begin{array}{c}\mathrm{MCV} \geq 80\left(\mu \mathrm{m}^{3}\right)=35 \\
(70.00 \%)\end{array}$ \\
\hline & $\begin{array}{l}\text { Hematocrit }<40 \% \\
\quad=41(82.00 \%)\end{array}$ & $\begin{array}{c}\text { Hematocrit } \geq 40 \% \\
=09(18.00 \%)\end{array}$ \\
\hline \multirow{4}{*}{$\begin{array}{l}\text { Menopausal } \\
\text { Diabetic }\end{array}$} & $\begin{array}{c}\mathrm{Hb}<12.0 \mathrm{gm} / \mathrm{dl}=42 \\
(70.00 \%)\end{array}$ & $\begin{array}{c}\mathrm{Hb} \geq 12.0 \mathrm{gm} / \mathrm{dl}=18 \\
(30.00 \%)\end{array}$ \\
\hline & $\begin{array}{l}\mathrm{RBC}<4.2(\text { million/ } \\
\left.\mathrm{mm}^{3}\right)=13(21.67 \%)\end{array}$ & $\begin{array}{l}\mathrm{RBC} \geq 4.2 \text { (million/ } \\
\left.\mathrm{mm}^{3}\right)=47(78.33 \%)\end{array}$ \\
\hline & $\begin{array}{c}\operatorname{MCV}<80\left(\mu m^{3}\right)=29 \\
(48.33 \%)\end{array}$ & $\begin{array}{c}M C V \geq 80\left(\mu m^{3}\right)=31 \\
(51.67 \%)\end{array}$ \\
\hline & $\begin{array}{l}\text { Hematocrit }<40 \% \\
\quad=48(80.00 \%)\end{array}$ & $\begin{array}{l}\text { Hematocrit } \geq 40 \% \\
\quad=12(20.00 \%)\end{array}$ \\
\hline
\end{tabular}

\begin{tabular}{|c|c|c|c|c|c|}
\hline \multirow[b]{2}{*}{ Categories } & \multirow[b]{2}{*}{ Non-Anemic } & \multicolumn{4}{|c|}{ Anemic } \\
\hline & & Overall & $\begin{array}{c}\text { Mild } \\
(\mathrm{Hb}<12)\end{array}$ & $\begin{array}{c}\text { Moderate } \\
(\mathrm{Hb}<11)\end{array}$ & $\begin{array}{l}\text { Severe } \\
(\mathrm{Hb}<8)\end{array}$ \\
\hline Menstruating Normal & $25(50.00 \%)$ & $25(50.00 \%)$ & $19(38.00 \%)$ & $06(12.00 \%)$ & $00(00 \%)$ \\
\hline Menstruating Diabetic & $29((48.33 \%)$ & $31(51.67 \%)$ & $12(20.00 \%)$ & $19(31.67 \%)$ & $00(00 \%)$ \\
\hline Menopausal Normal & $24((48.00 \%)$ & $26((52.00 \%)$ & $15(30.00 \%)$ & $11(22.00 \%)$ & $00(00 \%)$ \\
\hline Menopausal Diabetic & $18(30.00 \%)$ & $42(70.00 \%)$ & $18(30.00 \%)$ & $24(40.00 \%)$ & $00(00 \%)$ \\
\hline
\end{tabular}




\section{DISCUSSION}

The overall prevalence of anemia in menstruating normal, menstruating diabetics, menopausal normal, menopausal T2 diabetic were reported $50.00 \%$, $51.67 \%, 52.00 \%$ and $70.00 \%$ respectively. The trend of anemia in all categories was Menopausal diabetics $>$ Menopausal Normal >menstruating diabetics $>$ menstruating normal.

The iron deficiency anemia in reproductive age female of Korea is $11.5 \%{ }^{13}$, anemia among the female students of University of Sharjah was $26.7 \%{ }^{14}$ and in Pakistan among the young girls is $80.37 \%$ which is the highest in area ${ }^{6}$. In this study the menstruating normal group is showing $50.00 \%$ prevalence which is higher than the rest of the world, however less than the prevalence which was shown in comparatively young normal menstruating females ${ }^{6}$. The recent research suggest that the diabetes mellitus could possibly be a strong risk factor for anemia, the prevalence of anemia in diabetic female $(35.8 \%)$ is reported higher than male $(21.3 \%)$ in a study carried out at Dasman diabetes Institute Kuwait ${ }^{15}$. According to another study high prevalence of anemia was found in type II diabetes patients in male as well as in female ${ }^{16}$. On the contrary, the prevalence anemia is reported similar in diabetic or non-diabetic individuals ${ }^{17}$. To this end, no any significant difference wasfound in both groups. Additionally; whether or not the menopausal status of the women could affect the anemic condition or not was also observed in diabetic type II or normal female. The prevalence of anemia in pre-menopausal women (aged between $45-55$ ) is $86 \%$ and in post-menopausal women is $81 \%{ }^{18}$, moreover according to Russian study, anemia is inversely and strongly associated with menopausal status of women ${ }^{19}$. However, no any concluding research is available indicating the association of menopause with anemia. To this end the prevalence of anemia was reported not only in menopausal women but also the diabetic menopausal versus normal menopausal women in order to confirm whether the diabetic condition could influence the menopausal status (or vice versa) with reference to hemoglobin level or/and other anemic indicators. Till to date, no any datum is available pinpointing on the prevalence of anemia (and/or it comparison) in aforementioned categories. The same study with similar groups is suggested with different nationalities and mega sample size in order to confirm the existing prevalence in some novel groups. Hematocrit less than $40 \%$ was found $94 \%$ in menstruating normal. $(71.67 \%)$ in menstruating diabetic. $(82 \%)$ in menopausal normal $(80 \%)$ in menopausal diabetic respectively.

Kannan $S$ et al ${ }^{20}$ revealed that Hematocrit, MCV, $\mathrm{MCHC}$, and $\mathrm{Hb}$ have proved to be a reliable indicator of discordance in menstruating and menopausal diabetic females. Present study results have the similar findings.
The current study will provide the awareness about iron status and anemia peculiarly in a target group of female (diabetic mellitus and/or menopause), it will also be helpful to make the public health policy in a particular group of women.

\section{CONCLUSION:}

The study concludes that the prevalence of anemia in menopausal diabetic is more pronounced than in the other three study groups that are normal menstruating, diabetic menstruating and normal menopausal females. This is suggestive that cessation of menstruation added with diabeties is high risk factor for anemia.

Ethical permission: University of Sindh permission Letter No. Physiol/IRB/-399, dated: 06-012018.

Conflict of Interest: There is no conflict of interest.

Funding: There was no funding from any agency or institution.

\section{ACKNOWLEDGEMENT}

I am grateful to physiology department and all staff members who helped me in every stage of this research.

\section{REFERENCES}

1. Organization $\mathrm{WH}$. Haemoglobin concentrations for the diagnosis of anaemia and assessment of severity. World Health Organization, 2011. Available from: https://www.who.int/vmnis/ indicators/haemoglobin/en/

2. Talpur S, Afridi HI, Kazi TG, Talpur FN. Interaction of lead with calcium, iron, and zinc in the biological samples of malnourished children. Biol Trace Elem Res. 2018; 183(2): 209-17. doi: 10.1007/s12011-017-1141-9.

3. Faheem B, Warsi J, Shah T. Prevalence of anemia and its association with anthropometric indices in affluent male University students. Rawal Med J. 2019; 44(2): 233-6.

4. Anjum A, Manzoor M, Manzoor N, Shakir HA. Prevalence of anemia during pregnancy in district Faisalabad, Pakistan. Punjab Univ J Zool. 2015; 30(1): 15-20.

5. Saydam BK, Genc RE, Sarac F, Turfan EC. Prevalence of anemia and related factors among women in Turkey. Pak J Med Sci. 2017; 33(2): 433-8.doi: 10.12669/pjms.332 .11771

6. Laghari Z, Baig N, Memon F, Panhwar F, Qambarani M, Palh Z. Correlation of BMI and MUAC with anemia among Sindh University Students, Jamshoro, Pakistan. Sindh Univ Res J (Sci Ser). 2017; 49(3): 553-6.

7. Shah T, Shaikh F, Ansari S. To Determine the Effects of Green Tea on Blood Pressure of 
Healthy and Type 2 Diabetes Mellitus (DM) Individuals. J Liaquat Uni Med Health Sci. 2017; 16(04): 200-4. doi:10.22443/jlumhs.171640533.

8. Zafar J, Nadeem D, Khan SA, Jawad Abbasi M, Aziz F, Saeed S. Prevalence of diabetes and its correlates in urban population of Pakistan: A Cross-sectional survey. J Pak Med Assoc. 2016; 66(8): 922-7.

9. Shaikh F, Rafiq M, Bhutto MA, Naqvi SH. Exposure of Fat Mass Obesity Gene Polymorphism in Diabetes Mellitus Type-II Females of Hyderabad, Sindh. J Liaquat Uni Med Health Sci. 2019; 18(03): 231-5. doi:10.22443/ jlumhs. 191830633.

10. Barbieri J, Fontela PC, Winkelmann ER, Zimmermann CE, Sandri YP, Viera Mallet EK, et al. Anemia in Patients with Type 2 Diabetes Mellitus. Anemia. 2015; 354737: 1-7.

11. Singh N, Shinde M, Dafal H, Trivedi A, Chouhan Y. Age at natural menopause and factors affecting menopausal age: A cross-sectional study among postmenopausal female attendees of obstetrics and gynecology outpatient department. Int J Med Sci Public Health. 2018; 7(12): 994-1001.

12. Obeagu El, Obarezi HC, Ochei K, Okafor C, Iwegbulam C, Obeagu G, et al. Evaluation of Variations of Haematological Profile of Menopausal Women in Umuahia, Nigeria. Sch Acad J Biosci. 2016; 4(12): 1109-12.

13. Lee JO, Lee JH, Ahn S, Kim JW, Chang H, Kim YJ, et al. Prevalence and risk factors for iron deficiency anemia in the Korean population: results of the fifth Korea National Health and Nutrition Examination Survey. J Korean Med Sci. 2014;29(2):224-9. doi: 10.3346/ jkms.2014.29.2. 224
14. Sultan AH. Anemia among female college students attending the University of Sharjah, UAE: prevalence and classification. J Egypt Public Health Assoc. 2007; 82(3-4): 261-71.

15. Alsayegh F, Waheedi M, Bayoud T, Al Hubail A, Al-Refaei $F$, Sharma $P$. Anemia in diabetes: Experience of a single treatment center in Kuwait. Prim Care Diabetes. 2017;11(4):383-8. doi: 10.1016/j.pcd.2017.04.002.

16. Lee AR, Yun JM. Relationship between Diabetes Mellitus and Anemia in Korean Adults-Based on the Korean National Health and Nutritional Examination Survey VI. J Korean Diet Assoc. 2017; 23(1): 54-63. doi:10.14373/JKDA.2017.23. 1.54 .

17. Antwi-Bafour S, Hammond S, Adjei JK, Kyeremeh R, Martin-Odoom A, Ekem I. A case-control study of prevalence of anemia among patients with type 2 diabetes. J Med Case Rep. 2016; 10: 110. doi: 10.1186/s13256-016-0889-4

18. Bikbov MM, Kazakbaeva GM, Zainullin RM, Salavatova VF, Gilmanshin TR, Yakupova DF, et al. Prevalence and associated factors of anemia in a Russian population: the Ural eye and medical study. BMC Public Health. 2019; 19(1): 762. doi: 10.1186/s12889-019-7016-6.

19. Bishnoi S. To assess the prevalence of iron deficiency anaemia in menopausal women. Int $\mathrm{J}$ Home Sci. 2018; 4(2): 08-10.

20. Kannan S, Jaipalreddy C, Annapandian VM, Murali Mohan B, Damodar S, Khadilkar KS, et al. Impact of anemia and red cell indices on the diagnosis of pre-diabetes and diabetes in Indian adult population: Is there a cut-off guide for clinicians? Indian J Endocrinol Metab. 2019; 23 (1): 91-6.

AUTHOR AFFILIATION:
Dr. Shafaq Ansari (Corresponding Author)
Department of Anaesthesiology
Liaquat Medical Hospital Jamshoro/Hyderabad, Sindh-Pakistan.
Email: shafaqansaree@hotmail.com
Dr. Jamshed Warsi
Department of Physiology
University of Sindh, Jamshoro, Sindh-Pakistan.
Dr. Zulfiqar Laghari
Department of Physiology
University of Sindh, Jamshoro, Sindh-Pakistan.

